\title{
A CONSTITUTIVE MODEL FOR PLAIN CONCRETE SUBJECTED TO STATIC LOADING
}

\author{
Tavio* $^{*}$
}

\begin{abstract}
A numerical model based on the new theoretical micromechanical and lattice models has been proposed to simulate the fracture behavior of concrete specimens. The numerical model has been developed to implement the proposed theoretical micromechanical model using finite element method which employing the lattice model. Using the program developed, the numerical model has been used to simulate concrete specimens under direct tension and bending load conditions. Close agreement between the numerical results and the experimental data in literature indicated that the model is reasonably good, even in predicting the crack development. The numerical lattice model can, therefore, be an effective and useful tool for the analysis of the micro-structural behavior of concrete and for the design of concrete structures.
\end{abstract}

Keywords: Mori-Tanaka method, spring-layer model, interface, mortar, lattice model.

\begin{abstract}
ABSTRAK
Sebuah model numerik berdasarkan pada model mikromekanika teoritis dan jejaring baru diusulkan untuk mensimulasi perilaku fraktur benda-benda uji beton. Model numerik tersebut dikembangkan untuk menerapkan model mikromekanika teoritis yang diusulkan memakai metoda elemen hingga dengan menerapkan model jejaring. Dengan menggunakan program yang dikembangkan, model numerik tersebut digunakan untuk mensimulasi benda-benda uji beton di bawah kondisi beban tarik langsung dan lentur. Kesesuaian yang baik antara hasil-hasil numerik dan data eksperimen dalam literatur menunjukkan bahwa model tersebut cukup baik, bahkan di dalam memprediksi perkembangan retak. Maka dari itu, model numerik jejaring dapat menjadi sebuah alat yang efektif dan berguna untuk analisis perilaku mikro-struktural beton dan untuk perancangan strukturstruktur beton
\end{abstract}

Kata kunci: bidang-kontak, metoda Mori-Tanaka, model jejaring, model lapis-pegas, mortar.

\section{INTRODUCTION}

A lot of research works, driven by the development of powerful computer, have used the simulation methods of concrete's material behavior based on some simplified models for microstructure of concrete. Most of them applied the theory of continuum mechanics. Since there are more initial defects and large initial cracks within concrete compared with those in the basic components-coarse aggregates, interfaces, and mortar within concrete, this kind of model cannot fully capture the material crack behavior. Generally, these parameters are not the real material properties. Therefore, some discrete models for concrete were developed with a system of discrete elements in the forms of particles, trusses, or frames. This kind of models does not implement the material continuously, but to replace the continuum by an array of discrete elements in the forms of particles in contact, trusses, or frames, in such a manner that the displacements are defined only at the centers of the particles, or at the nodes of the truss or frame.

The beginning of the particle approach could be traced back to the development of the distinct element method by Cundall (1971), Serrano and Rodriguez-Ortiz (1973), Kawai (1980); Cundall and Strack (1979), in which the behavior of material was analyzed by the interactions of particles in contact. Later, the method of particle model was extended further to simulate the behavior of brittle composite materials, especially for concrete. This was done by Zubelewicz and Bazant (1987); Mohamed and Hansen (1999). For computational purposes, the basic element was reduced to a truss, or a frame. Although the truss element and simple constitutive relation of material are employed in those researches, the prediction of mechanical properties of material is shown to be reasonable. In this research, a new numerical micromechanical model, which combines the micromechanical theoretical model with the lattice model together, is presented. Comparisons with experimental data from literature show that the model is reasonably accurate, even in predicting the crack development.

\section{A LATTICE MODEL FOR THE MICROMECHANICAL MODEL}

In the normal finite element models, continuum element models are employed to deal with the mechanical behavior of concrete. However, a special assembly of discrete elements, lattice model, is usually implemented in such a way to simplify the problem. More

\footnotetext{
* Jurusan Teknik Sipil, FTSP ITS, Jl. Arief Rahman Hakim (60111)

E-mail: tavio@its.ac.id
}

Majalah IPTEK - Vol. 18, No. 2, Mei 2007 
efforts can be focused on the material behavior itself. In this research, the lattice model is used to simulate the behavior of concrete. In the proposed model, the axial interaction between neighboring points is considered as a truss. The initial modulus of truss is the initial elastic modulus of concrete. With the increase of loading, the modulus of truss will decrease. There are two types of truss failure, shown in Figure 1. Based on the micromechanical model, constituent relations of tension and compression for concrete follow the theoretical micromechanical model with consideration of different phases of concrete. Using the micromechanical model, the typical compressive and tensile stress-strain curve is shown in Figures 2 and 3, respectively. Most of numerical micromechanical models for concrete in the framework of lattice models consider the basic constitutive relation of concrete as linear elastic for compression and simple linear or exponential decay for tension. For each phase of concrete, some empirical ratio for different phases of concrete is given to calculate the modulus and strength of each phase. Since they consider the details of each phase and the coarse aggregates or the interfaces between mortar and aggregates, enormous elements are needed.

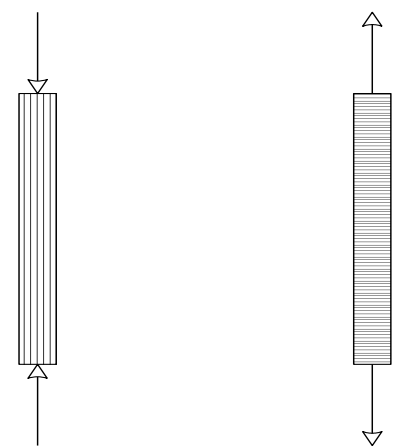

Figure 1. Failure model of truss element.

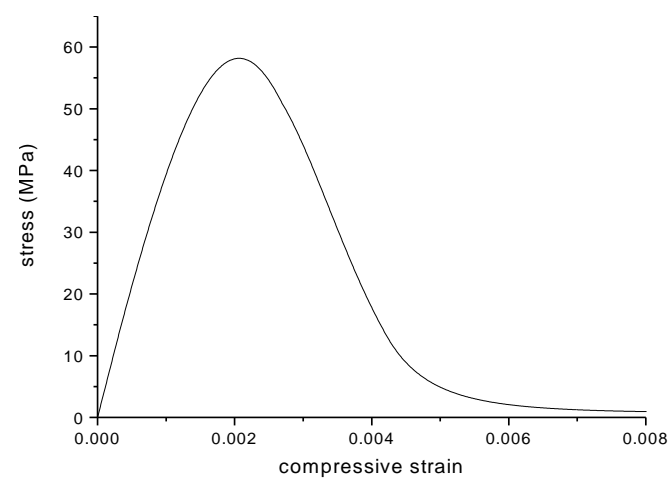

Figure 2. Typical uniaxial compression.

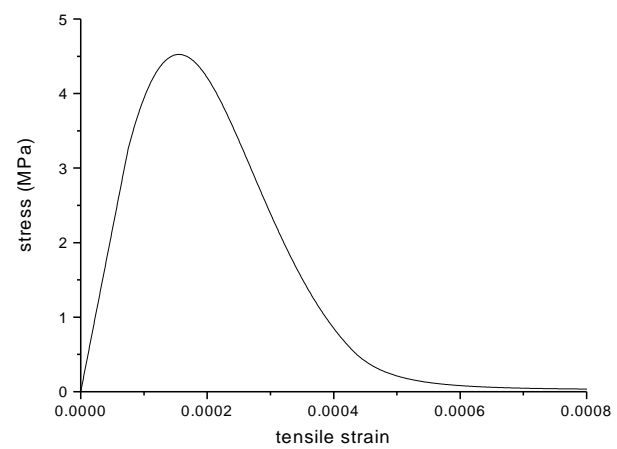

Figure 3. Typical uniaxial tension.

In this research, the basic constitutive relations of concrete are derived based on the Mori-Tanaka method, and then the equations are used in the modified lattice model for concrete to predict the behavior of concrete in compression and tension as well as in flexural bending. The modified lattice model is combined with the proposed micromechanical model. The new numerical model is used to predict the behavior of concrete under two-dimensional problems. At the same time, it only requires fewer elements compared with the previously proposed numerical micromechanical models. The model can, thus, save much computational time and storage space in the process.

\subsection{Mesh Generation}

In this research, PDE toolbox of MATLAB is employed to create the regular triangle mesh. From the information of elements and nodes, the elements and nodes of the truss elements can, then, be formed. If there are some notches in the specimens, more elements will be provided in the zones nearby the notches and FEMLAB is used to create the mesh.

\subsection{Formulation of the Element Stiffness Matrix}

The application of nonlinear behavior of material in the finite element program is a difficult problem, particularly in the vicinity of the peak point of load-displacement curve. The most common approaches for dealing with such a problem are the secant and tangential methods. In the proposed micromechanical model, the current modulus of concrete is calculated based on the corresponding global tensile strain and then used in the secant model with some changes. It is shown in the following flowchart (Figure 4) that the stiffness matrix of element is built according to the given element displacement. 


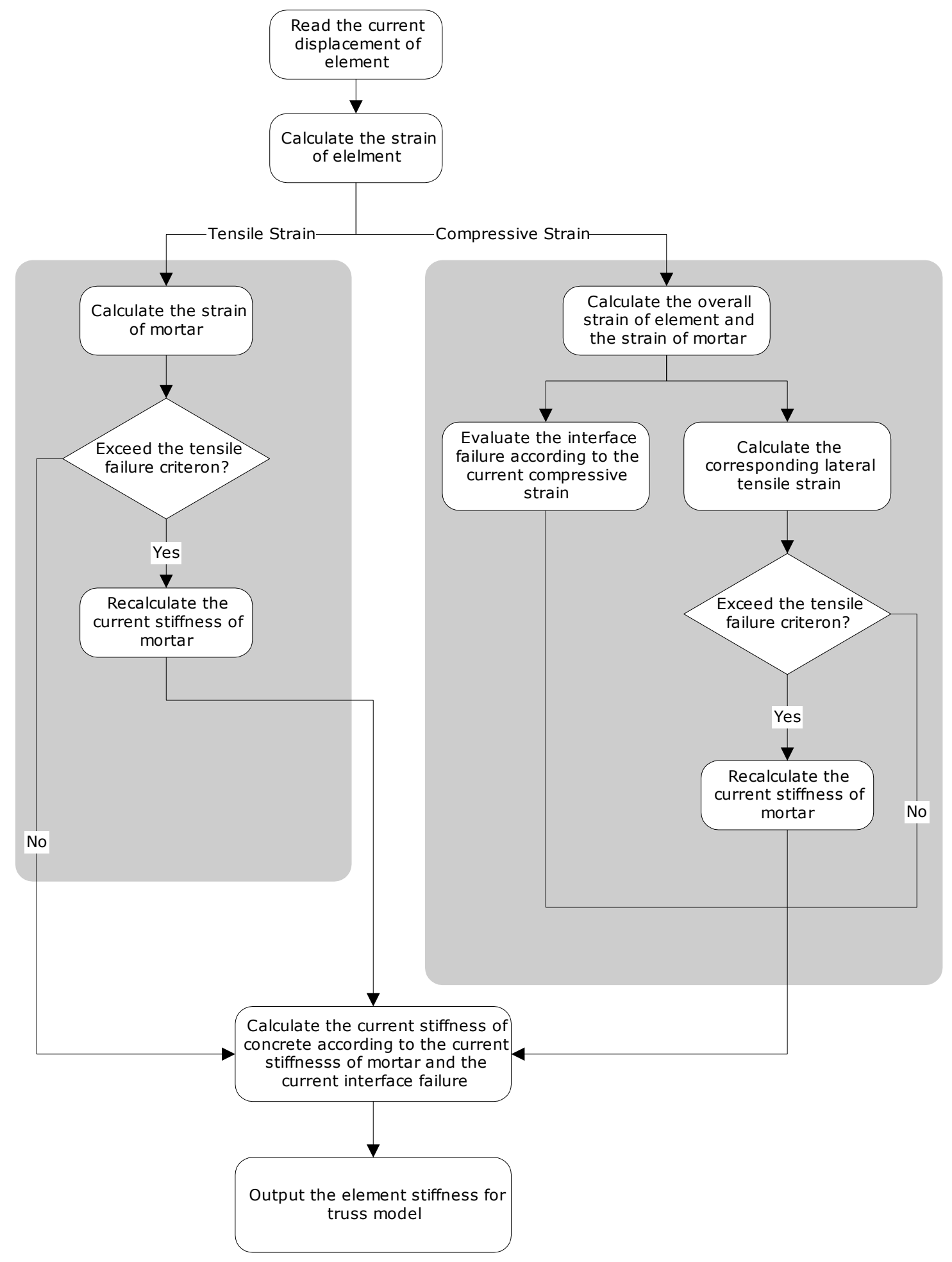

Figure 4. Flowchart for element stiffness. 
In order to solve the element stiffness matrix, the element displacement $u_{i}$ should be calculated in accordance with the overall stiffness and displacement or external force. If $u_{i}$ is known, the strain of element $i$ is given by $\varepsilon_{i}=u_{i} / L_{i}$

Inside the truss element, the element is allowed to have the lateral strain as a two dimensional problem with the only axial-directional force.

The vector of strain for the element in twodimensional problem is separated as the two parts, i.e., compressive strain $\varepsilon_{C}$ and tensile strain $\varepsilon_{T}$

$$
\begin{aligned}
& \varepsilon_{C}=\left\{\varepsilon_{1}\right\} \\
& \varepsilon_{T}=\left\{\begin{array}{l}
\varepsilon_{2} \\
\varepsilon_{12}
\end{array}\right\}
\end{aligned}
$$

with only axial-directional force in truss element, $\varepsilon_{1}=\varepsilon_{i}$

The vector of stress for the element can also be separated as follows

$$
\begin{aligned}
& \sigma_{C}=\left\{\sigma_{1}\right\} \\
& \sigma_{T}=\left\{\begin{array}{l}
\sigma_{2} \\
\sigma_{12}
\end{array}\right\}
\end{aligned}
$$

For the truss element, $\varepsilon_{C}$ and $\sigma_{T}$ can, thus, be determined

$\varepsilon_{C}=\left\{\varepsilon_{i}\right\}$

$$
\sigma_{T}=\left\{\begin{array}{l}
0 \\
0
\end{array}\right\}
$$

The corresponding modulus matrix for the element could also be separated as follows

$$
L_{E}=\left[\begin{array}{ccc}
\frac{E}{1-v^{2}} & \frac{E v}{1-v^{2}} & 0 \\
\frac{E v}{1-v^{2}} & \frac{E}{1-v^{2}} & 0 \\
0 & 0 & \frac{E}{2(1+v)}
\end{array}\right]=\left[\begin{array}{cc}
L_{C C} & L_{C T} \\
L_{T C} & L_{T T}
\end{array}\right]
$$

with

$$
\begin{aligned}
L_{C C} & =\frac{E}{1-v^{2}} \\
L_{C T} & =\left[\begin{array}{cc}
\frac{E v}{1-v^{2}} & 0
\end{array}\right] \\
L_{T C} & =\left[\begin{array}{c}
E v \\
1-v^{2} \\
0
\end{array}\right]
\end{aligned}
$$

$$
L_{T T}=\left[\begin{array}{cc}
\frac{E}{1-v^{2}} & 0 \\
0 & \frac{E}{2(1+v)}
\end{array}\right]
$$

The other unknown strain and stress can be calculated by the following equations

$$
\begin{aligned}
& \varepsilon_{T}=L_{T T}{ }^{-1}\left(-L_{T C} \varepsilon_{C}\right) \\
& \sigma_{C}=L_{C T} \varepsilon_{T}+L_{C C} \varepsilon_{C}
\end{aligned}
$$

Therefore, the overall stress of element is expressed as

$\sigma=\left\{\begin{array}{c}\sigma_{C} \\ 0 \\ 0\end{array}\right\}$

According to the failure situation in the last iterating step, the current Eshelby tensor for concrete could be calculated by

$S=c_{i} S_{d}+\left(1-c_{i}\right) S_{d}$

where $c_{i}$ is the failure volume of interface, $S_{d}$ is Eshelby tensor for failure interfaces and $S_{p}$ is Eshelby tensor for perfect interfaces.

Then, in accordance with the Mori-Tanaka method, the current stress of mortar could be calculated as,

$$
\sigma_{0}=\left(c_{0} I+c_{1} W\right) \sigma
$$

with

$$
W=\left(I+\bar{L}_{0}(I-S)\left(L_{1}^{-1}-\bar{L}_{0}^{-1}\right)\right)^{-1}
$$

And the corresponding strain of mortar could be obtained by the following equation,

$$
\varepsilon_{0}=\bar{L}_{0}^{-1} \sigma_{0}
$$

For evaluating the situation of mortar failure, the principal strain of mortar should be calculated by,

$$
\begin{aligned}
& \varepsilon_{01}=\frac{\varepsilon_{1}+\varepsilon_{2}}{2}+\sqrt{\left(\frac{\varepsilon_{1}-\varepsilon_{2}}{2}\right)^{2}+\left(\frac{\varepsilon_{12}}{2}\right)^{2}} \\
& \varepsilon_{02}=\frac{\varepsilon_{1}+\varepsilon_{2}}{2}-\sqrt{\left(\frac{\varepsilon_{1}-\varepsilon_{2}}{2}\right)^{2}+\left(\frac{\varepsilon_{12}}{2}\right)^{2}}
\end{aligned}
$$

If $\varepsilon_{01}$ exceeds the tensile strain criterion of concrete (Neville, 1996), the current modulus of mortar should be recalculated by the following equation

$\bar{L}_{0}=L_{0}-c_{m} L_{0} T_{m}\left(\left(1-c_{m}\right) I+c_{m} T_{m}\right)$

with

$$
\begin{aligned}
& T_{m}=\left(\left(1-c_{m}\right)\left(I-S_{m}\right)\right)^{-1} \\
& S_{m}=T S_{0} T^{T}
\end{aligned}
$$

where $T$ is the transformation matrix of coordinate and $T^{T}$ is the transpose matrix of $T$. 
When the strain is in tension for the truss element, the expression of $T$ is shown as follows

$$
T=\left[\begin{array}{ccc}
0 & 1 & 0 \\
1 & 0 & 0 \\
0 & 0 & -1
\end{array}\right]
$$

However, when the strain is in compression, the expression of $T$ is given by,

$$
T=\left[\begin{array}{lll}
1 & 0 & 0 \\
0 & 1 & 0 \\
0 & 0 & 1
\end{array}\right]
$$

At the same time, when the corresponding failure volume ratio of mortar is calculated by Eq. (28), which follows Weibull distribution, the current modulus of mortar can be obtained by Eq. (23).

$$
c_{m}=\frac{1-e^{-\left(\frac{\left|\varepsilon_{01}-\varepsilon_{\text {tensile }}\right|}{\varepsilon_{u}-\varepsilon_{\text {tensile }}}\right)^{m_{m}}}}{1-e^{-1}}
$$

From the above equation, it can be seen that the value of $c_{m}$ would be approaching unity and the stiffness of element would be reaching zero after the strain reaches a large value. Thus, if the proposed constitutive model for concrete is implemented in the program code, serious numerical problems would be encountered. Hence, after the failure volume ratio of mortar reaches a large value, the modified constitutive relationship is used instead of the original constitutive relationship. In order to avoid numerical difficulty during the process, at a large value, the following modified failure volume ratio of mortar, which was derived based on the modified constitutive relationship, should be used.

$$
\bar{C}_{m}=a e^{-e^{b-c C_{m}}}
$$

where

$a=0.971, \quad b=3.266, \quad c=6.134$

when

$C_{m}>0.78$

This way, the value of failure volume ratio of mortar would never be reaching unity, hence the stiffness of concrete would also never be approaching zero.

If the second principal strain of concrete is in compression, the failure volume ratio of interfaces can be computed by the following equation,

$c_{i}=\frac{1-e^{-\left(\frac{\left|\varepsilon_{02}\right|}{\varepsilon_{u}}\right)^{m}}}{1-e^{-1}}$

The current modulus of concrete could, thus, be solved as follows

$$
L=\left(1-c_{i}\right) L_{p}+c_{i} L_{d}
$$

with

$$
\begin{aligned}
& L_{d}=\bar{L}_{0}+c_{1}\left(L_{1}-\bar{L}_{0}\right) T_{d}\left(c_{0} I+c_{1} T_{d}\right)^{-1} \\
& L_{p}=\bar{L}_{0}+c_{1}\left(L_{1}-\bar{L}_{0}\right) T_{p}\left(c_{0} I+c_{1} T_{p}\right)^{-1} \\
& \text { and } \\
& T_{d}=\left(I+\left(c_{0} S_{d}+c_{1} I\right)\right)^{-1} \bar{L}_{0}^{-1}\left(L_{1}-\bar{L}_{0}^{-1}\right) \\
& T_{p}=\left(I+\left(c_{0} S_{p}+c_{1} I\right)\right)^{-1} \bar{L}_{0}^{-1}\left(L_{1}-\bar{L}_{0}^{-1}\right)
\end{aligned}
$$

During the computation, the current modulus matrix of the element has to be transferred to the element stiffness matrix using the following equations

$E_{0}=\left(1-\bar{v}^{2}\right) L_{11}$

with

$\bar{v}=L_{21} / L_{22}$

The current element stiffness matrix could then be calculated using Eq. (33).

$K^{e}=\frac{E A}{L}\left[\begin{array}{cc}1 & -1 \\ -1 & 1\end{array}\right]$

The ratio of the cross-sectional area $A$ to the element length $L$ is considered as a constant $(\sqrt{3} / 2)$ based on the works of (Hrennikoff 1941; Mohamed 1997).

\subsection{Development of Computer Program}

The displacement control method has been used to handle the finite element problem in the current research. The overall stiffness matrix is subdivided into four sub-matrices corresponding to the prescribed and free degrees of freedom by the following equations (Crisfield 1991; Mohamed 1997).

$$
\left(\begin{array}{ll}
K_{f f} & K_{f p} \\
K_{p f} & K_{p p}
\end{array}\right)\left[\begin{array}{l}
U_{f} \\
U_{p}
\end{array}\right]=\left[\begin{array}{l}
P_{f} \\
P_{p}
\end{array}\right]
$$

where $f$ and $p$ refer to the free and prescribed degrees of freedom, respectively. From Eq. (34), the unknowns $U_{f}$ and $P_{p}$ can be found as follows

$$
\begin{aligned}
& \left.\left[U_{f}\right]=\left(K_{f f}\right)\right)^{-1}\left(\left[P_{f}\right]-\left[K_{f p}\right]\left[U_{p}\right]\right) \\
& {\left[P_{p}\right\rfloor=\left(K_{p f}\right)\left\lfloor U_{f}\right\rfloor+\left(K_{p p}\right)\left[U_{p}\right\rfloor}
\end{aligned}
$$

The computer program employs a nonlinear finite element incremental displacement scheme with an iterative procedure based on the successive approximation method (Owen and Hinton 1980).

The program starts with identifying the geometry, the coordinates of each element and the mesh layout from the data files, which is created by PDE toolbox of MATLAB. Then, the incremental solution starts with decomposing the stiffness matrix, load and 
displacement vector as free and prescribed parts according to Eq. (34). After obtaining the corresponding unknown displacement and load vectors, the displacements at the nodes could also be found. The strain in each element is then calculated and checked with the current element status. If the new strain value in an element indicates that the element status has changed in the iteration, the new stiffness is assigned to the corresponding element and the overall stiffness is calculated based on the updated status. After updating the status of all elements, the program continues to the next increment and records the required information for the current increment if the ratio between the norm of the current displacement vector and the last iterating displacement vector satisfies the prescribed tolerance. Otherwise, the iteration procedure continues.

\section{MODEL PREDICTION FOR DIRECT TENSION}

The proposed numerical model is applied to simulate the behavior of single-edge-notched specimen under direct tension. At the same time, the process of localization and development of cracks was studied based on the proposed model. The first example is employed for a plain mortar specimen under direct tension (Maji and Shah 1988). The geometry of the specimen is shown in Figure 5. The corresponding mesh layout is depicted in Figure 6. The corresponding material properties used in the specimen are shown Table 1. The load-deformation response under splitting tension, which was simulated by the proposed numerical model, is shown in Figure 7. From the figure, it can be seen that the simulation results are in good agreement with the experimental data tested by Maji and Shah (1988). The crack pattern during the loading process illustrated in Figure 8 also shows that the crack patterns at various loading stages can simulate the actual crack developments of the specimen.

\section{MODEL PREDICTION FOR THREE- POINT BENDING}

Bending is a typical loading pattern in concrete structures. Since it relates with tension, compression and shear, its behavior is quite complicated. Hence, many researches are focused in this topic either theoretically or experimentally. Numerous specimens have been tested under bending in the past three decades. In this research, a typical example is selected to be compared with the results of the numerical simulations.

Petersson (1980) has carried out several three-point bending tests on the notched beams. A typical three-point bending beam from Petersson's test results was used to study the capability of the proposed numerical model in predicting the behavior of the beam in bending. The dimensions of specimens are described in Figure 9. The corresponding material properties are given in Table 2. The mesh layout is illustrated in Figure 10. The load-displacement curves at various loading stages are plotted in Figure 11. From the figure, it is shown that the simulation curve based on the proposed model can closely predict the response of the actual beam. The crack patterns shown in Figure 12 are also in close agreement with the corresponding experimental crack patterns at various loading stages.

\section{MODEL PREDICTION UNDER COMPRESSIVE LOADING}

The behavior of concrete under compressive loading is also one of the most important issues. Extensive researches have been focused on studying its behavior either theoretically or experimentally. In this research, a proposed numerical micromechanical model is used to simulate the behavior of concrete specimen under compression.

A typical specimen under compressive loading was selected from Kupfer et al's experiment (1969) for simulation. The specimen has dimensions of $200 \times 200 \times 50 \mathrm{~mm}$ and its geometry is shown in Figure 13. The mesh layout is displayed in Figure 14. The corresponding material properties are listed in Table 3. The axial stress-deformation curves are shown in Figure 15. From the figure, it shows that the model is able to predict most of the experimental observed phenomena for concrete under compression, including softening and localization of deformation. However, the

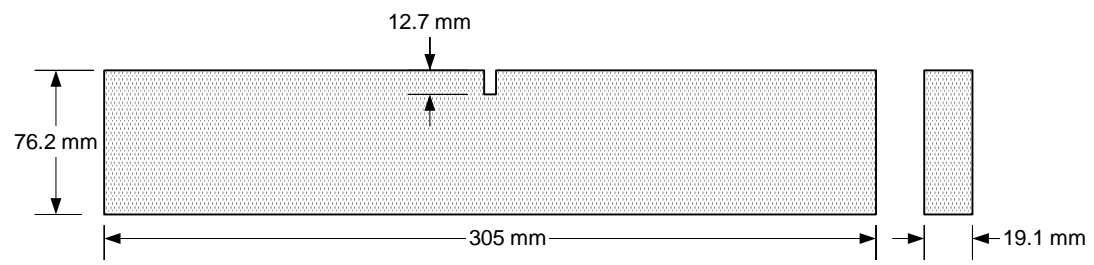

Figure 5. Single-edge notched specimen for mortar. 
prediction on the deformation at ultimate load gives a slightly lower value than the corresponding experimental value. Many researchers (Van Mier 1997, Bazant and Planas 1998; Mohamed 1997) have pointed out the problems and gave some explanations on this issue. This is not a drawback in the model since it can predict almost all the observed phenomena. The drawback is rather in the way the specimen is simulated. Compressive behavior of concrete is a triaxial direction, and the crack surfaces are usually located in more than a single plane. Thus, a three-dimensional simulation is essential for predicting the compressive behavior of concrete. However, the prediction of the current two-dimensional model is still able to provide valuable information on the response of concrete under compression. Since it is beyond the current computational efforts to conduct three-dimensional simulations, no further investigation on the compressive behavior of concrete was conducted.

\section{CONCLUSION}

The proposed micromechanical model has been introduced in the current research to simulate the mechanical behavior of concrete under different loading states. These loading states include tension, bending, and compression. The model predictions on the responses and crack patterns were found to be in good agreement with the experimental results. However, the current model has slightly underestimated the compressive deformation at peak loading point. A three-dimensional analysis is, therefore, required for predicting a more accurate compressive behavior of concrete.

\section{REFERENCES}

Bazant, Z. P., and Planas, J. (1998), Fracture and Size Effect in Concrete and Other Quasibrittle Materials, CRC Press.

Crisfield, M. A. (1991), Nonlinear Finite Element Analysis of Solids and Structures, John Wiley \& Sons, Inc.

Cundall, P. A. (1971), 'A Computer Model for Simulating Progressive Large Scale Movements in Blocky Rock Systems', Proceeding of International Symposium of Rock Fracture.

Cundall, P. A., and Strack, O. D. L. (1979), 'A Discrete Numerical Model for Granular Assemblies', Geotechnique, Vol. 29, No. 1, pp. 47-65.
Hrennikoff, A. (1941), 'Solution of Problems of Elasticity by the Framework Method', Journal of Applied Mechanics, Dec., pp. 169-175.

Kawai, T. (1980), 'Some Considerations on the Finite Element Method', International Journal of Numerical Mechanical Engineering, Vol. 16, pp. 81-120.

Kupfer, H., Hilsdorf, H. K., and Rusch, H. (1969), 'Behaviour of Concrete under Biaxial Stresses', ACI Journal, August, pp. 656-666.

Maji, A., and Shah, S. P. (1988), 'Process Zone and Acoustic-Emission Measurements in Concrete', Experimental Mechanics, Vol. 28, pp. 27-33.

Mohamed, A. R. (1997), Micromechanics of Concrete Behavior and Progressive Failure under Static Loading, Ph.D. Thesis, University of Michigan.

Mohamed, A. R., and Hansen, W. (1999), 'Micromechanical Modelling of Concrete Response under Static Loading - Part 1: Model Development and Validation', $A C I$ Materials Journal, Vol. 96, No. 2, pp. 196-203.

Mohamed, A. R., and Hansen, W. (1999), 'Micromechanical Modelling of Concrete Response under Static Loading - Part 2: Model Prediction for Shear and Compressive Loading', ACI Materials Journal, Vol. 96, No. 2, pp. 354-358.

Neville, A. M. (1996), Properties of Concrete, John Wiley, New York.

Owen, D. R. J., and Hinton, E. (1980), Finite Element in Plasticity-Theory and Practice, Pineridge Press, Swansea.

Petersson, P. E. (1980), 'Fracture of Energy of Concrete: Practical Performance and Experimental Results', Cement and Concrete Research, Vol. 10, pp. 91-101.

Serrano, A. A., and Rodriguez-Ortiz, J. M. (1973), 'A Contribution to the Mechanics of Heterogeneous Granular Media', Proceedings of Symposia Plasticity and Soil Mechanics.

Van Mier, J. G. M. (1997), Fracture Processes of Concrete, CRC Press Inc.

Zubelewicz, A., and Bazant, Z. P. (1987), 'Interface Element Modeling of Fracture in Aggregate Composites', ASCE Journal of Engineering Mechanics, Vol. 113, pp. 1619-1630.

Diterima: 22 Maret 2006

Disetujui untuk diterbitkan: 14 Februari 2007 


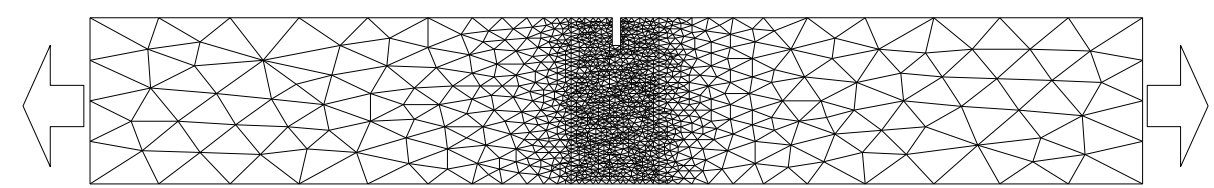

Figure 6. Mesh layout of lattice model for single-edge notched specimen.

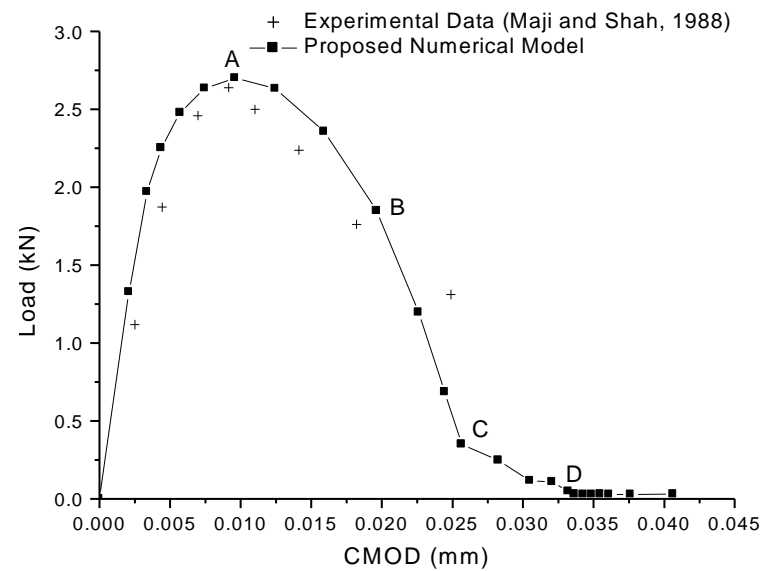

Figure 7. Theoretical and experimental load-CMOD curves for single-edge notched specimen.
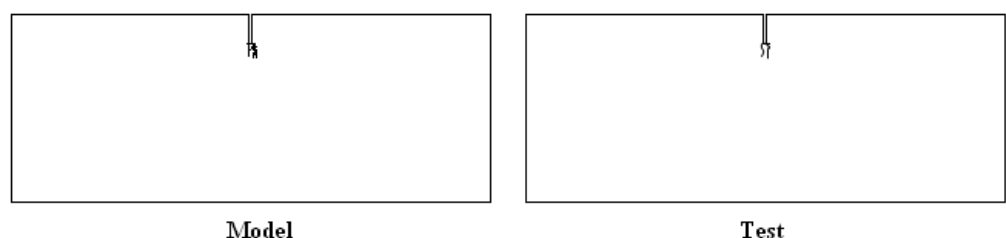

(a) At Loading Point A

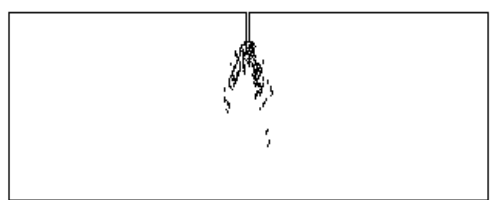

Model

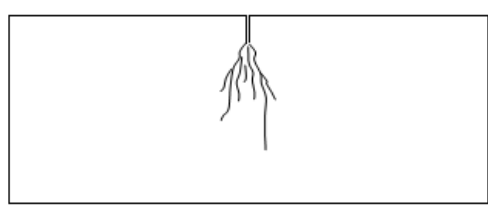

Test

(b) At Loading Point B

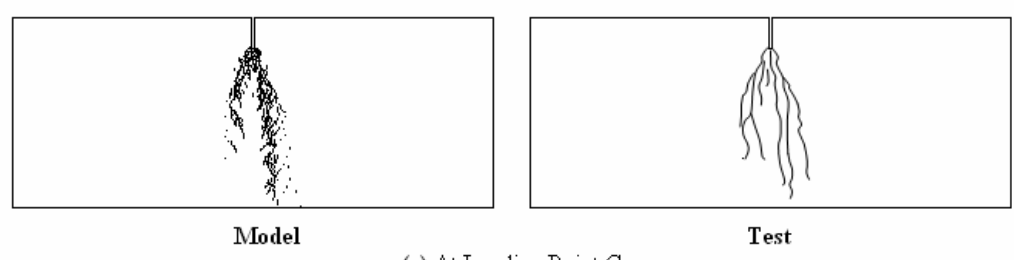

(c) At Loading Point $\mathrm{C}$

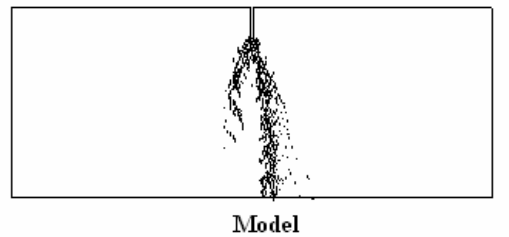

(d) At Loading Point D

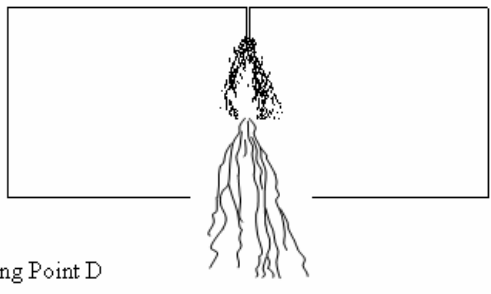

Figure 8. Crack patterns at various loading points for single-edge notched specimen. 


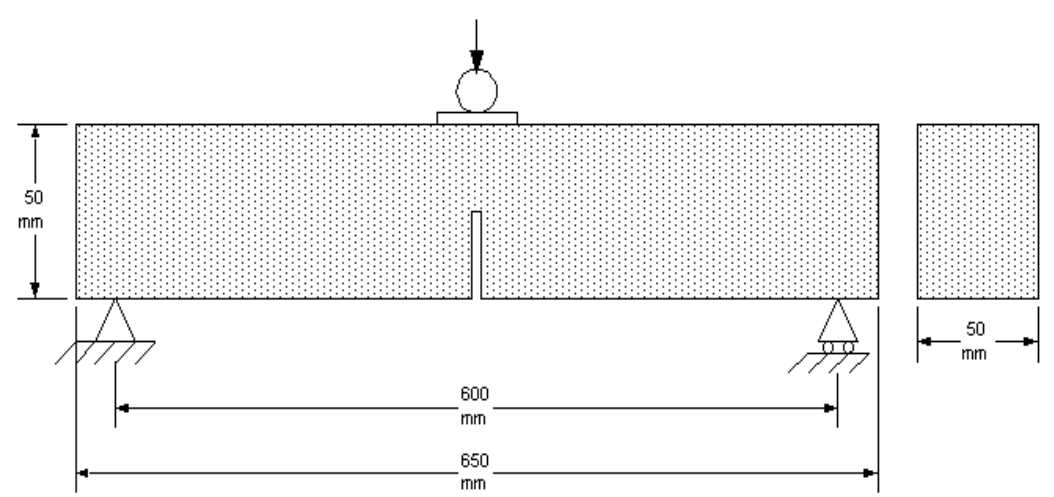

Figure 9. Notched beam for three-point bending.

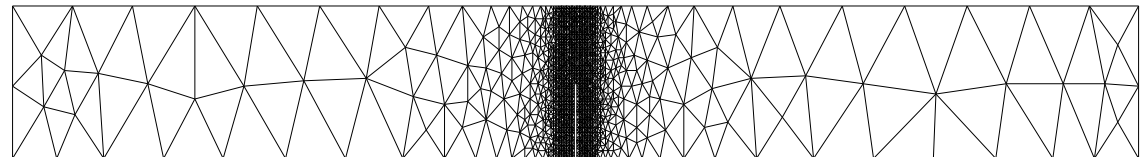

Figure 10. Mesh layout of lattice model for three-point bending.

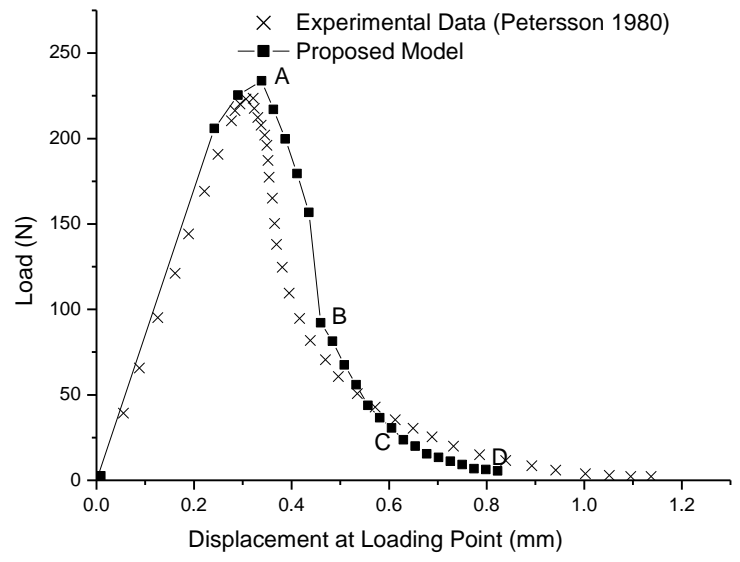

Figure 11. Theoretical and experimental load-displacement curves for three-point bending.

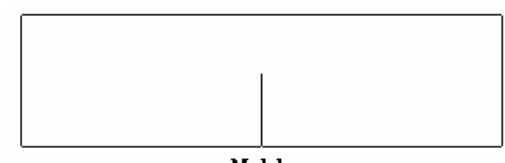

Model

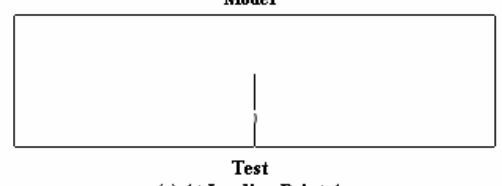

(a) At Loading Point A

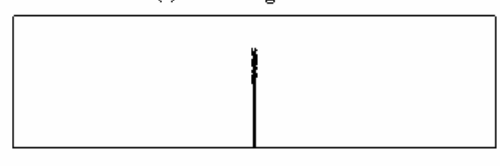

Model

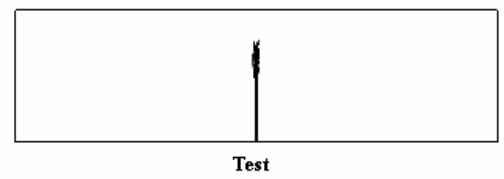

(b) At Loading Point B

Figure 12. Crack patterns at various loading points for three-point bending. 

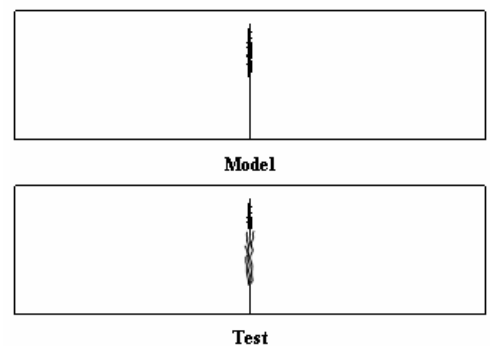

(c) At Loading Point $\mathrm{C}$
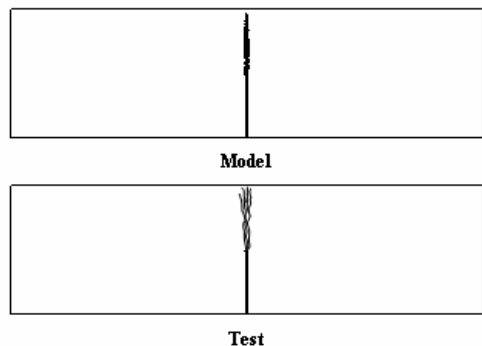

Figure 12. Continued.

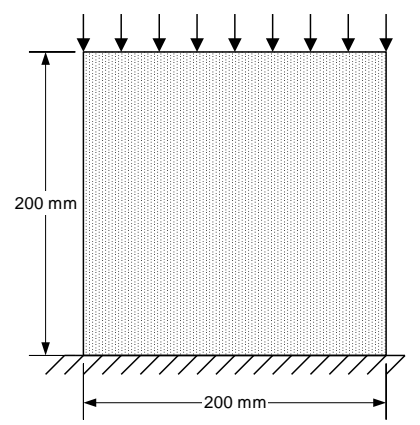

Figure 13. Specimen configuration for compression simulation specimen configuration for compression simulation.

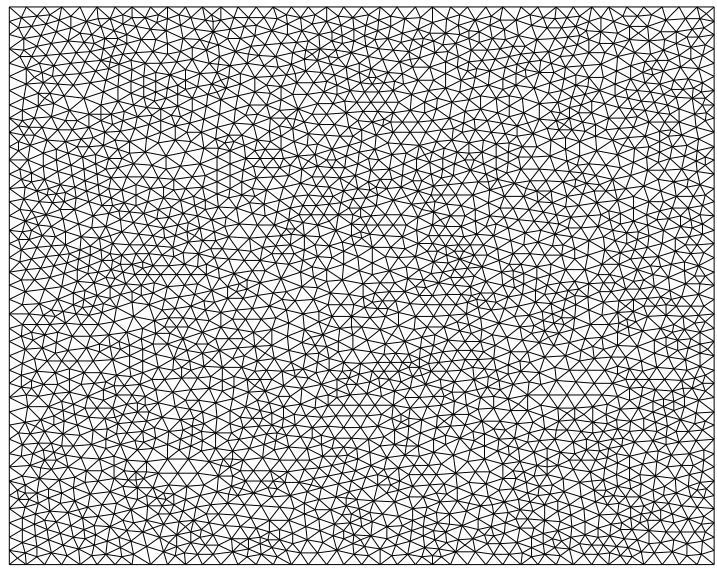

Figure 14. Mesh layout of lattice model for compression simulation.

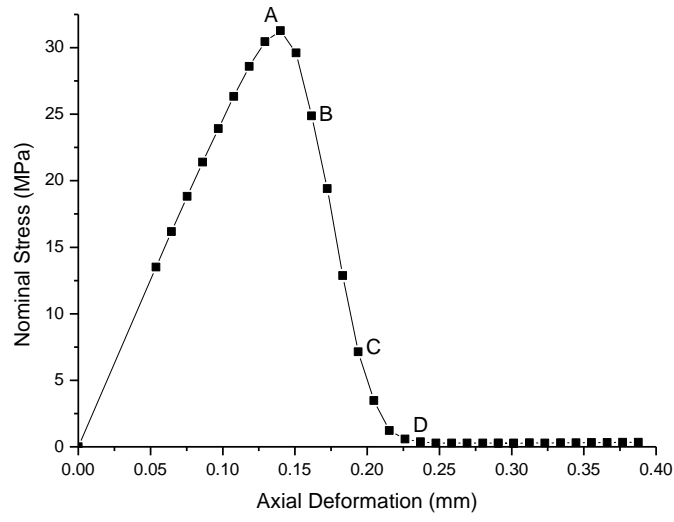

Figure 15. Theoretical and experimental stress-axial deformation curves under compression 